\title{
Social skills in adolescence: Psychopathology and sociodemographic variables
}

\author{
Habilidades sociais na adolescência: psicopatologia \\ e variáveis biosociodemográficas
}

\author{
Jean Von HOHENDORFF \\ Maria Clara Pinheiro DE PAULA COUTO \\ Laíssa ESCHILETTI PRATI
}

\begin{abstract}
This study aimed to investigate the relationship between social skills, psychopathology and sociodemographic characteristics among adolescents. Participants were 50 adolescents from Rio Grande do Sul, Brazil (30 girls and 20 boys, $M_{\text {age }}=14$ years, SD=1.61) who attended either a public or a private school. The participants answered a sociodemographic questionnaire, the social skills Inventory for Adolescents Del-Prette (frequency and difficulty) and, to assess symptoms of psychopathology, the Self Report Questionnaire 20. Results indicated that there were no differences in the frequency of the social skills investigated with regard to genders, age, type of school attended, and the indication of psychopathology. However, the difficulty score reported on the use of social skills was related with psychopathology. This relationship was further moderated by the type of school. Thus, sociodemographic variables and personal characteristics (such as psychopathology) must be considered in social skills studies.
\end{abstract}

Uniterms: Adolescence; Psychopathology; Social skills; Sociodemographic.

\section{Resumo}

O objetivo deste estudo foi investigar relações entre habilidades sociais, indicativo de psicopatologia e variáveis biossociodemográficas em adolescentes. A amostra foi composta por 50 adolescentes de uma cidade do Rio Grande do Sul ( 30 meninas e 20 meninos, $M_{\text {idade }}=14$ anos, $D P=1,61$ ) que frequentavam ou escola particular ou escola pública. Os participantes responderam a um questionário biossociodemográfico, o Inventário de habilidades sociais para Adolescentes de Del-Prette e, para avaliar sintomas de psicopatologia, o SelfReport Questionnaire 20. Os resultados indicaram que não houve diferença na frequência das habilidades sociais investigadas quanto às variáveis sexo, idade, escola e indicativo de psicopatologia. Todavia, foi constatado que a intensidade da dificuldade em habilidades sociais está relacionada com o indicativo de psicopatologia apresentado pelos adolescentes. Esta relação foi moderada pelo tipo de escola. Assim, além do papel de variáveis biossociodemográficas, as características individuais (por exemplo, psicopatologia) devem ser consideradas em estudos sobre habilidades sociais.

Unitermos: Adolescência; Psicopatologia; Habilidades sociais; Variáveis sociodemográficas.

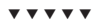

- Universidade Federal do Rio Grande do Sul, Centro de Estudos Psicológicos, Programa de Pós-Graduação em Psicologia. R. Ramiro Barcelos, 2600, Sala 104, Santa Cecília, 90035-003, Porto Alegre, RS, Brasil. Correspondência para/Correspondence to: J.V. HOHENDORFF. E-mail: <jhohendorff@gmail.com>.

2 Faculdades Integradas de Taquara, Curso de Psicologia. Taquara, RS, Brasil. 
Social skills are characterized by a set of behaviors displayed by individuals in an interpersonal context in which they express feelings, attitudes, desires, opinions or rights adequately for the situation, respecting the same behavior in others (Caballo, 1986). They are therefore characterized by the performance of the individuals given the demands of a social situation. These skills are learned and the performance level differs depending on the developmental stage and on cultural and situational variables (Z.A.P. Del Prette \& A. Del Prette, 1999).

The development of social skills is influenced by two distinct factors: the individual temperament (individual characteristics) and environment (contextual variables). The temperament is configured by the tendency that the individual has to relate socially. Thus, for example, children born with a predisposition to behave in a more inhibited way tend to engage less in activities that give them the opportunity to learn and practice social behaviors, which may result in less reinforcement (praise, smiles, caresses etc.) by the people around them. Conversely, it is likely that children who are more outgoing are involved in social interactions in which they will have the opportunity to develop their social behavioral repertoire (Caballo, 2003). The influence of the temperament on the development of social skills can be counterbalanced by the environmental factor. This is because the environment acts to reinforce (or not) social behaviors, as well as enabling the learning of new skills through observation and interactions (Caballo, 2003).

Adolescence is a developmental stage in which the social skills play an important role considering the need for social integration and the search for self-assertion and independence. It is therefore a stage of the life cycle where adaptations and changes in personal and social skills need to be made. However, infancy is often considered a critical period for learning social skills (Caballo, 2003) and many researchers are devoted to the study of this subject (Bandeira, Rocha, Freitas, Z.A.P. Del Prette \& A. Del Prette, 2006; Bandeira, Rocha, Pires, Z.A.P. Del Prette \& A. Del Prette, 2006; Bandeira, Rocha, Souza, Z.A.P. Del Prette \& A. Del Prette, 2006; Bolsoni-Silva, Marturana, Pereira \& Manfrinato, 2006; Branco \& Ferreira, 2006; Z.A.P. Del Prette \& A. Del Prette, 2002; Gonçalves \& Murta, 2008).

Although infancy is a phase relevant to the

152 development of social skills, it is known that in adolescence, the peers influence the development, serving as models and sources of reinforcement for the social skills (Caballo, 2003). The period of adolescence has specific characteristics, including the tendency for group interaction, which indicates the propensity that the adolescent has to relate to peer groups. This group tendency (Knobel, 1981) is derived from the individual's need to identify with someone (or something, such as sports activities) so that they can construct their own identity, with this being considered the main task of adolescence (Erikson, 1972). The group tendency and the acquisition of identity are, therefore, relevant aspects in the experience of adolescence, which require social interactions, since it is from the interaction with others that the sense of identity is formulated.

Indications of psychopathology (e.g., depressed mood, anxiety, and somatization) and sociodemographic variables (e.g., gender and age) have the potential to influence social skills during adolescence. For example, Wagner and Oliveira (2007) conducted a review of the literature on social skills and substance abuse by adolescents. The authors reviewed scientific papers in the field of relationships between social skills and psychological disorders, verifying that they are present mainly in disorders such as schizophrenia, depression, emotional disorders, affective and anxiety disorders, invasive disorders, such as autism, and psychoactive substances abuse and dependence (Z.A.P. Del Prette \& A. Del Prette, 2002; Falcone, 2000). The results of this study indicate that adolescents who abuse or are dependent upon psychoactive substance may have deficits in social skills, thereby setting up an inverse relationship between social skills and drug use. Deficits in social skills among adolescent substance users are configured in the form of low social skills and specific difficulties such as those manifested in situations of risk to the self-esteem and problem solving. Furthermore, the desire for acceptance by the peer group can be related to the limited ability for refusing (group pressure for drug use ends up prevailing (Wagner \& Oliveira, 2007).

Two types of social skills seem to be especially important for a good experience of adolescence: assertiveness and self-control (Bakker, Ormel, Lindenberg, Verhulst \& Oldehinkel, 2010). Socially skilled adolescents are able to express their feelings and desires, managing to control their impulses and alter emotions 
and thoughts. Furthermore, deficits in social skills favor victimization among the peers and conflict with authorities. The victimization and conflict resulting from deficits in social skills, when lasting, can result in mental problems (Bakker et al., 2010). Individuals with good social skills have a low chance of developing depression and being lonely and socially anxious (Segrin \& Flora, 2000). Thus, the studies indicate an interaction of the deficits in social skills with victimization among peers and psychiatric disorders (Bakker et al., 2010; Segrin \& Flora, 2000; Wagner \& Oliveira, 2007). Conversely, socially skilled behaviors are seen as favorable for the development of strategies when faced with adverse situations, reducing vulnerability and enhancing resilience (Cecconello \& Koller, 2000).

In a study carried out with adolescents, Landazabal (2006) investigated the relationships between psychopathological symptoms, social skills, cooperation and personality traits (emotional stability, openmindedness, sociability and responsibility). The repertoire of behaviors was evaluated in five dimensions: social skills (behaviors such as expressing emotions, making friends and sharing); inappropriate assertiveness (aggressive behaviors, such as mocking and abusing others); impulsivity (getting angry easily and interrupting others); overconfidence (overestimating themselves); and jealousy/withdrawal (loneliness and lack of friends). The results showed that adolescents who presented psychopathological symptoms had low levels of cooperative behaviors and social skills. At the same time, these adolescents presented high scores in inappropriate assertiveness, impulsivity, overconfidence, and jealousy/ withdrawal. Regarding the personality variables, higher levels of psychopathologies were associated with low scores in emotional stability, sociability and responsibility. This study supports the hypothesis that psychopathological symptoms and social skills are inversely related, with high levels of psychopathology being associated with low levels of social skills.

By shifting the focus to the influence of context variables on social skills, the study by Campos, Z.A.P. Del Prette and A. Del Prette (2000) examined the values of children and adolescents in homeless situations and their relationship with the development of social skills. A total of 28 boys in homeless situations, from less than ten years of age to 18 years of age, were investigated.
Through informal conversations, recorded interviews and the application of an inventory regarding skills, beliefs and feelings, the authors concluded that the children and adolescents developed a set of relevant social skills to cope with the demands of the homeless situation. Skills such as defending their rights, negotiating interests, and refusal and acceptance of requests were the most frequent. Conversely, skills related to the expression of positive feelings, asking questions, dealing with criticism and mockery, and controlling anxiety were presented less frequently. These results show the influence of the context on the social skills, considering that the skills most present in this study population were consistent with their contextual requirements.

The study of social skills, with respect to the sociodemographic variables, is still incipient (Bandeira et al., 2006), even though the social behavior occurs in a given context and is influenced by this. Variables such as gender, age, marital status, family configuration, profession, education, personal and family gains, and living in rural or urban areas, among others, are considered important for the development of social skills (Caballo, 2003). Relevant data in relation to variables such as age, gender, type of School and Socioeconomic Status (SES) are also described by Z.A.P. Del Prette and A. Del Prette (2009). In a comparison between groups of adolescents of different ages (12 to 14 and 15 to 17 years) in which the Inventário de Habilidades Sociais para Adolescentes (IHSA, Social Skills Inventory for Adolescents) (Z.A.P. Del Prette \& A. Del Prette, 2009) was used, the older individuals presented higher scores on the IHSA-Del-Prette civility, social assertiveness and resourcefulness subscales. Regarding gender differences, the results indicated that, when they appear, these are favorable for adolescent girls, both in the frequency indicators (higher scores) as well as in those of difficulty (lower scores). No differences were found in social skills according to the type of school attended by the adolescents (i.e., private or public). The frequency and difficulty in social skills showed distinct differences between the different socioeconomic conditions. When the social skills were correlated with the SES, the results indicated a positive correlation between the total frequency score of the social skills and the SES, as well as between the total difficulty score and the SES.

Given the above, it can be considered that psychopathology indications and sociodemographic variables have the potential to influence social skills 
during adolescence. Thus, this study aimed to investigate the possible relationship between social skills, psychopathology indications and sociodemographic variables among adolescents.

\section{Method}

\section{Participants}

A total of 50 adolescents, 25 being from a private school and 25 from a public school, girls $(n=30)$ and boys ( $n=20$ ), aged between 12 and 17 years (Media $M=14$ years, Standard Deviation - SD=1.61) from a city of Rio Grande do Sul, Brazil participated in this study. The schools and participants were chosen by convenience. The selection procedure for the participants was started in the private school, and later, the formation of a paired sample was sought in the public school using the following criteria: grade, gender and age. The exclusion criteria adopted were: difficulty in comprehending and responding to the instruments, not being included in the 12 to 17 years age group, and the Terms of Free Prior Informed Consent (TFPIC) not being signing by those responsible for the adolescent. The majority of the adolescents were attending the seventh grade of elementary education (30.0\%), and $24.0 \%$ were in the first year of high school education. The second year of high school and the sixth grade of elementary education presented rates of $22.0 \%$ and $16.0 \%$, respectively. The adolescents of the eighth grade presented the lowest frequency, with $8.0 \%$. Regarding the results of the Self Report Questionnaire 20 (SRQ-20), 22.0\% of the participants had scores indicating the presence of psychopathology. Of these, $81.8 \%$ were female and 18.2\% male.

\section{Instruments} collection:

The following instruments were used for the data

Social Skills Inventory for Adolescents (Z.A.P. Del Prette \& A. Del Prette, 2009): an instrument reviewed and approved by the Federal Council of Psychology, which presented favorable psychometric properties of reliability and accuracy in the original version $(\alpha=0.90$ for the total frequency score and $\alpha=0.90$ for the total difficulty score). In this study, the analysis of reliability of the instrument was $\alpha=0.96$ for the total frequency score, and $\alpha=0.94$ for the total difficulty score. It consists of 38 items that assess relationship skills with different interlocutors, required in public, private or unspecified contexts. The adolescents have to judge: (a) how often they present the reaction indicated in the item and (b) their difficulties in presenting this reaction; on two Likert type scales, producing an general score for frequency and another for difficulty. The scale for the frequency score has five interval options (i.e., 0-2; 3-4; 5-6; 7-8; 9-10), which indicate the frequency that respondents perform the behavior described in the items having the total number of ten situations as the parameter. Each of these options is converted into points from zero to four, with zero being equivalent to the frequency of $0-2$ and four to the frequency 9-10. The options for the difficulty scale also have four answer choices (i.e., Very easy; Fairly easy; Average; Fairly difficult; Extremely difficult), which are converted into points ranging from zero to four, where $0=$ Very easy, $4=$ =xtremely difficult. The instrument also produces scores on six subscales for both frequency and difficulty: 1) Empathy ("Noting that a colleague is sad or in trouble, I offer my support"), 2) Self-control ("I can control my anger when my brother/sister irritates me somehow"), 3) Civility ("When someone does me a favor or a kindness, I thank them"), 4) Assertiveness ("When I do not like an item of clothing or shoe that the salesperson insists I buy, I say politely that I do not like it and will not take it"), 5) Affective approach ("When I want to make friends, I invite people to go out or do an activity"), and 6) Social resourcefulness ("I talk easily about sex with my parents"). High scores in frequency and low scores in difficulty indicate a more developed social skills repertoire of the respondent. Conversely, the lower the scores of frequency and the higher the difficulty scores, the less developed the social skills repertoire of the respondent. The manual of the instrument suggests that the interpretation of the total raw scores and those of the subscales can be based on the position of the respondents in terms of percentiles, comparing these scores to the reference group of the same gender and age (Z.A.P. Del Prette \& A. Del Prette, 2009). However, in this study, the mean raw scores were used for the statistical analysis, without interpreting them by their percentiles. In Brazil, up to 2009, there were no instruments to assess standardized social skills for adolescents, which made research difficult (Z.A.P. Del 
Prette \& A. Del Prette, 2009). Thus, this study is characterized as one of the first to use the IHSA-DelPrette considering that this is a recently released instrument.

Self Reporting Questionnaire 20 (SRQ-20): used to generate indications of psychopathology, i.e., the presence of mental disorder symptoms. The SRQ-20 was developed by Harding, Arango, Baltazar, Climent and Ibrahim (1980) and validated in Brazil by Mari and Williams (1986). It is a self-reported instrument composed by 20 dichotomous questions (yes/no) that assess four groups of symptoms: depressed-anxious mood, ("Doyou feel nervous, tense or worried?"), somatic symptoms ("Do you have unpleasant sensations in the stomach?"), decrease of vital energy ("Do you feel tired all the time?") and depressive thoughts ("Have you had thoughts of ending your life"). For each affirmative answer, one point is added (i.e., the SRQ-20 scores can range from 0 to 20). The greater the presence of affirmative answers, the higher the likelihood of psychopathological disorders. A score of seven or more for male adolescents and eight or more for female adolescents indicate possible cases of psychopathological disorders, according to the study by Avanci, Assisi, Oliveira, Ferreira and Pesce (2007). In this study the total score on the SRQ-20 was considered, i.e., the four groups of symptoms were not analyzed separately.

Sociodemographic questionnaire: developed for this study in order to obtain data such as age, gender, education and type of school the adolescents attended.

\section{Procedures}

The study was approved by the Research Ethics Committee of the Faculdades Integradas de Taquara (FACCAT), protocol number 492, and all participants signed the TFPIC. Then, a contact was made with two schools (one public and one private) to request the Terms of Agreement for the performance of the study. After the agreement of the schools, a meeting was held with the adolescents in their respective schools to present the project and invite them to participate. At this meeting the TFPIC were distributed for the parents or guardians of the participants to sign, as the participants were minors. Only in the second meeting with the adolescents, at the premises of each school, were the instruments applied with those that had had their participation authorized. In a group, the students signed another TFPIC rewritten in language adapted to the adolescents, and the instruments were applied in the following order: 1) sociodemographic questionnaire; 2) IHSA-Del-Prette, 3) SRQ-20. The participants responded to the instruments in groups at extracurricular times, with a mean duration of 30 minutes.

\section{Results}

Initially, the data from the IHSA-Del-Prette were tabulated and the frequency and difficulty means were calculated. In the manual for the application, calculation and interpretation of the instrument (Z.A.P. Del Prette \& A. Del Prette, 2009), the authors worked with the overall score which was calculated from the sum of the items. In this study it was chosen to work with the overall means of frequency and difficulty and their respective subscales so that it was possible to identify the position of the respondent on the frequency (i.e., 0-2; 3-4; 5-6; 7-8; 9-10) and difficulty scales (i.e., Very easy; Fairly easy; Average; Fairly difficult; Extremely difficult), which would not be possible through the overall score. For comparison, the following variables were considered: gender, type of school (public vs. private), age (12-14 years vs. 15-17 years) and indication of psychopathology (SRQ-20, represented by scores $\geq 7$ for boys and $\geq 8$ girls).

The frequency mean of the IHSA-Del-Prette was $2.31^{3}$ (SD=0.84). The instrument considers the frequency from the number of times that the participant presents a specific reaction on a scale ranging from 0 to 4 (i.e., $0=0$ to 2 times and $4=9$ to 10 times). That is, the adolescents of the study reported reacting 5 to 6 times in the way described for the items of the instrument. Regarding difficulty, the adolescents presented a mean of $0.97^{4}$ (SD=0.53), indicating a little difficulty in dealing with the situations addressed in the instrument.

$\boldsymbol{\nabla} \mathbf{\nabla} \boldsymbol{\nabla}$

3 One participant (outlier) was excluded from the analysis of the frequency mean of the IHSA (i.e., $n=49$ ).

4wo participants (outliers) were excluded from the analysis of the difficulty mean of the IHSA (i.e., $n=48$ ). 
When considering the frequency mean, no significant differences were found in relation to gender, $t$-statistic(47) $=-0.36$, non significant (ns); age, $t(47)=-0.65$, ns; school type, $t(47)=0.53$, ns; and indication of psychopathology (SRQ-20, present vs. absent), t(47) $=0.47$, ns. That is, these variables did not differentiate the participants regarding the frequency in which they experience the situations mentioned in the IHSA-DelPrette.

The difficulty mean of the participants varied significantly between the boys $(\mathrm{M}=0.80, \mathrm{SD}=0.40)$ and girls $(M=1.09, S D=0.57), t(46)=1.95, p<0.05$ (one-tailed test), and between those who presented indication of psychopathology $(M=1.46, \mathrm{SD}=0.56)$ and those that did not $(M=0.85, S D=0.44), t(46)=-3.70, p<0.01$. Such differences also appeared when comparing the younger adolescents ( $M=0.83, S D=0.50)$ with the older ones $(M=1.11, S D=0.53), t(46)=-1.86, p<0.05$ (one-tailed test). The type of school was not a differentiating variable for the difficulty mean in the IHSA-Del-Prette, $t(46)=1.13$, ns.

Two covariance analyzes were performed aiming to verify whether the differences in the difficulty means

\section{Table 1}

Adjusted and unadjusted (for age and gender) means and variability of difficulty in social skills using the indication of psychopathology as a covariate

\begin{tabular}{llcccccc}
\hline & & \multicolumn{2}{c}{ Unadjusted } & & \multicolumn{2}{c}{ Adjusted } \\
\cline { 3 - 4 } \cline { 7 - 8 } & $n$ & $M$ & SD & & $M$ & SD \\
\hline Boys & 19 & 0.80 & 0.40 & & 0.93 & 0.12 \\
Girls & 29 & 1.09 & 0.57 & & 1.00 & 0.09 \\
\hline Younger & 23 & 0.83 & 0.50 & & 0.89 & 0.10 \\
Older & 25 & 1.11 & 0.53 & & 1.05 & 0.10 \\
\hline
\end{tabular}

Note: M: Mean; SD: Standard Deviation. in the IHSA-Del-Prette between the girls and boys and between the older and younger adolescents would still remain after controlling for the indication of psychopathology. For the gender variable, the results indicated that after the indication of psychopathology mean was controlled, there was no significant difference between the boys and girls, F-statistic (1.45) $=0.19$, ns, $R$-squared $=0.16$. The same occurred with the age variable, i.e. after indication of psychopathology was controlled, there was no significant difference between the younger and older adolescents, $F(1.45)=1.20$, ns, etasquared $=0.18$. Table 1 presents the means and variability of difficulty in social skills for boys and girls and for younger and older adolescents before and after the indication of psychopathology was controlled. There was no significant difference in relation to gender and age after the indication of psychopathology was controlled. This indicates that the difficulty in the IHSA-Del-Prette was not explained by the gender or age of the participants, but by the indication of psychopathology (Table 2).

Considering the frequency mean in the six subscales of the IHSA-Del-Prette (i.e., Empathy, Selfcontrol, Civility, Assertiveness, Affective approach, and Social resourcefulness), there were no differences in the variables analyzed (i.e., gender, age, school type and indication of psychopathology - SRQ-20) (Table 3). The difficulty means in the Empathy, $t(48)=-3.01, p<0.01$, Civility, $t(48)=-2.21, p<0.05$, Assertiveness, $t(48)=-3.55$, $p<0.01$, and Social resourcefulness, $t(48)=-3.65, p<0.01$ subscales, differed significantly considering the indication of psychopathology (SRQ-20). The participants who presented signs of psychopathology (SRQ-20) had more difficulties in the subscales mentioned (for the complete values of the means, see Table 1). The

\section{Table 2}

Analysis of covariance for the difficulty in social skills mean as a function of gender and age having the indication of psychopathology as a covariate

\begin{tabular}{lccccc}
\hline Variable & $\mathrm{df}$ & RMS & $F$ & $p$ & eta $^{1}$ \\
\hline Indication of psychopathology & 1 & 1.93 & 8.59 & $<0.01$ & 0.16 \\
Gender & 1 & 0.05 & 0.19 & 0.66 & 0.004 \\
Error & 45 & 0.22 & 10.17 & $<0.01$ & 0.18 \\
Indication of psychopathology & 1 & 2.24 & 1.20 & 0.28 & 0.03 \\
Age & 1 & 0.26 & & \\
Error & 45 & 0.22 & & \\
\hline
\end{tabular}

156

Note: df: degrees of freedom; RMS: Root Mean Square; F: F-statistic; eta': eta-squared. 
Table 3

Regression analyzes with the SRQ-20, gender, age and type of school as predictors of the difficulty mean in the IHSA-Del-Prette

\begin{tabular}{|c|c|c|c|c|c|}
\hline Variables & $B$ & SEB & $\beta$ & $t(46)$ & $p$ \\
\hline SRQ-20 & 0.16 & 0.08 & 0.33 & 2.07 & 0.05 \\
\hline Gender & -0.09 & 0.16 & -0.09 & -0.60 & 0.56 \\
\hline SRQ-20 x Gender & -0.09 & 0.22 & -0.08 & -0.42 & 0.68 \\
\hline SRQ-20 & 0.17 & 0.07 & 0.34 & 2.39 & 0.05 \\
\hline Age & 0.15 & 0.14 & 0.15 & 1.08 & 0.28 \\
\hline SRQ-20 $\times$ Age & -0.22 & 0.15 & -0.36 & -1.39 & 0.17 \\
\hline SRQ-20 & 0.20 & 0.07 & 0.39 & 2.72 & 0.01 \\
\hline Type of school & -0.07 & 0.14 & -0.07 & -0.47 & 0.64 \\
\hline SRQ-20 x Type of school & 0.30 & 0.14 & 0.46 & 2.06 & 0.05 \\
\hline
\end{tabular}

Note: SRQ-20: Self Report Questionnaire 20; IHSA-Del-Prette: Social Skills Inventory for Adolescents; $\beta$ : standardized coefficients; SEB: Standard Error of $B$; $t$ : $t$-statistic.

age variable differentiated the participants in relation to the difficulty mean in the Self-control subscale, $t(48)=-2.17, p<0.05$. The older participants (i.e., 15 to 17 years) reported more difficulty in this subscale (Table 1). Finally, there were significant differences in terms of the gender variable in the difficulty means of the Assertiveness $t(48)=2.06, p<0.05$, and Affective approach $t(48)=2.13, p<0.05$ subscales. The girls reported more difficulty than the boys in these subscales (Table 1).

Aiming to investigate in which of the IHSA-DelPrette subscales the adolescents reported greater frequency and difficulty, analyzes of variance for repeated measures were conducted for the frequency and difficulty means of the six subscales respectively. Regarding the frequency means of the six subscales, a main effect of Subscale $F(4.33,202.30)=24.18, p<0.001$ was found. Through planned contrasts (Empathy, Civility and Assertiveness vs. Social Resourcefulness, Affective Approach and Self-control), it was verified that the Empathy $(M=2.71, S D=1.00)$, Civility $(M=2.62, S D=1.31)$ and Assertiveness $(M=2.49, S D=1.07)$ subscales were the more frequent when compared to the Social resourcefulness $(M=1.99, S D=0.95)$, Affective approach $(M=1.86, S D=0.93)$ and Self-control $(M=1.80, S D=0.96)$ subscales, which were less frequent, $F(1.49)=121.34$, $p<0.001$ (Figure 1).

Regarding the difficulty means, a main effect of Subscale was also found, $F(3.60,176.65)=28.35, p<0.001$. Again, by means of planned contrasts (Self-control and Affective Approach vs. Empathy, Civility, Assertiveness and Social resource fulness) it was found that the Selfcontrol $(M=1.49, S D=0.81)$ and Affective approach
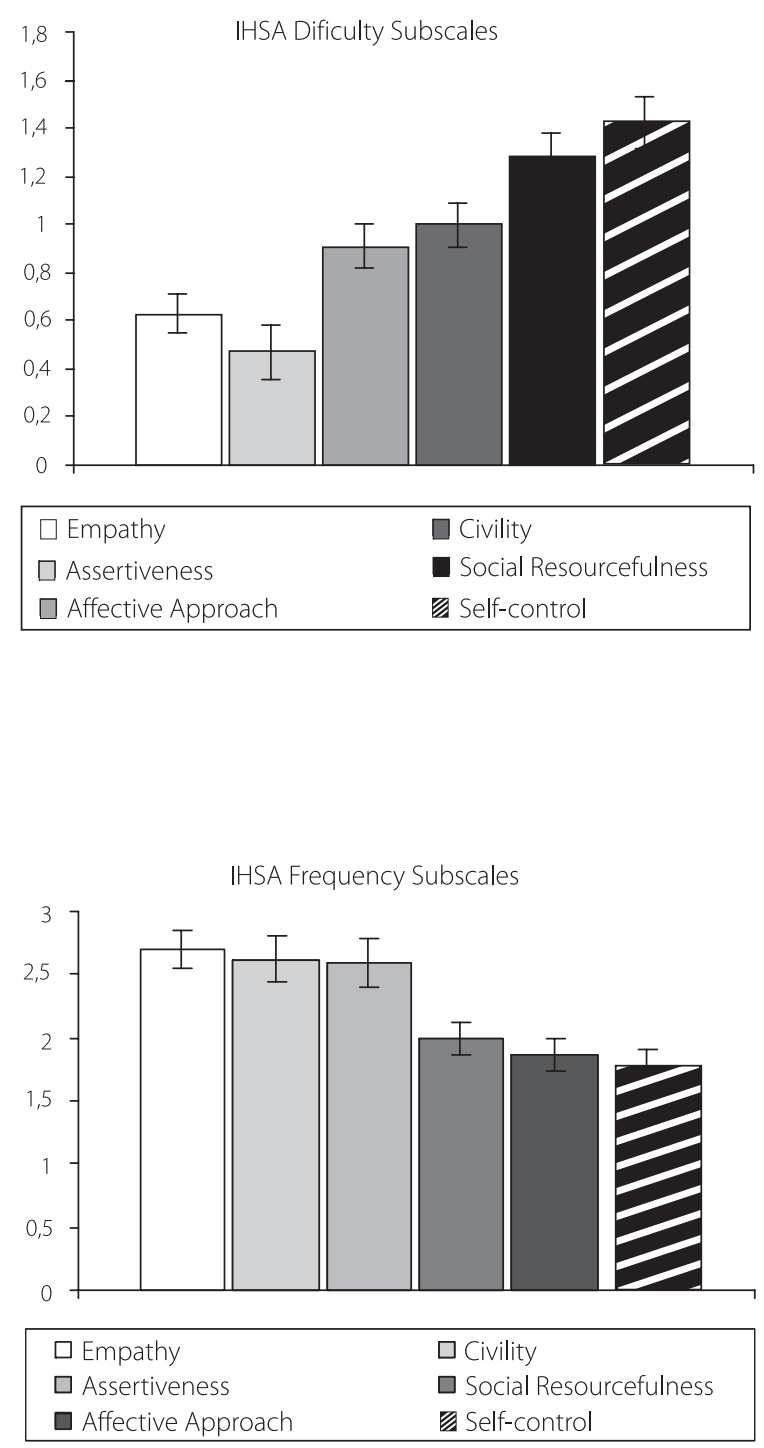

Figure 1. Difficulty and frequency means of the frequency and difficulty subscales of the IHSA-Del-Prette. 
$(M=1.33, S D=0.75)$ subscales were the ones with the highest difficulty mean in the IHSA-Del-Prette when compared to Empathy ( $M=0.73, S D=0.72)$, Civility $(\mathrm{M}=0.56, \mathrm{SD}=0.89)$, Assertiveness $(\mathrm{M}=0.98, \mathrm{SD}=0.76)$ and Social resourcefulness $(M=1.08, S D=0.73), F(1.49)=58.57$, $p<0.001$ (Figure 1).

\section{Analysis of the relationship between indication of psychopathology and difficulty in the IHSA-Del-Prette}

From the Analyzes of Covariance (Ancova), the indication of psychopathology emerged as an influencing factor in the difficulty in social skills. Thus, the predictor role of the indication of psychopathology in the difficulty in social skills was tested. A regression analysis was performed with the difficulty mean in the IHSA-Del-Prette as the dependent variable and the indication of psychopathology mean as an independent variable, and a significant relationship was found, $\beta=0.47$, $t(47)=3.61, p<0.01, R^{2}=0.20$.

In order to explore the relationship found between indication of psychopathology (SRQ-20) and the difficulty in social skills, the following variables were tested as potential moderators: gender, age and type of school. Thus, hierarchical regression analyzes were conducted, where in the first step, the independent variable (SRQ-20) and the moderator were inserted, and in the second step, the interaction of the two was analyzed. The dependent variable was the difficulty mean in the IHSA-Del-Prette. Prior to the performance of the analyzes, the independent variable (SRQ-20) was centralized and the moderators were converted into dummy type variables (i.e., $0=$ female and $1=$ male, $0=$ private and $1=$ public school, and $0=12$ to 14 years, $1=15$ to 17 years of age). The interactions of gender with the indication of psychopathology (SRQ-20), age with indication of psychopathology (SRQ-20) and school type with indication of psychopathology (SRQ-20) were then calculated. The relevant statistics are presented in Table 3.

Gender was not a significant moderator of the relationship between the SRQ-20 and social skills difficulty. The same occurred for age. However, the type of school was a significant moderator of the relationship 158 between the SRQ-20 and social skills difficulty. This

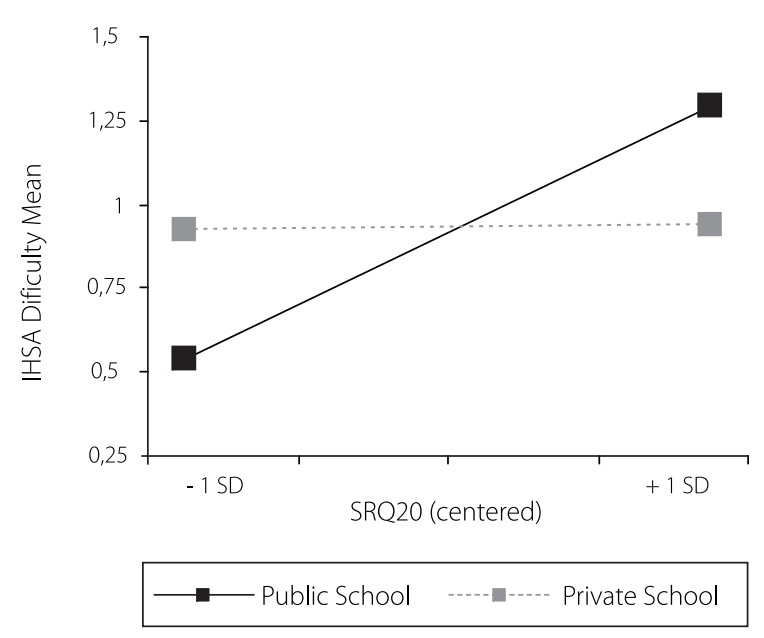

Figure 2. Relationship between SRQ-20 and difficulty of the IHSADel-Prette as a function of the type of school.

Note: SRQ-20: Self Report Questionnaire 20; IHSA-Del-Prette: Social Skills Inventory for Adolescents; SD: Standard Deviation.

relationship was only significant for the public school students $(\beta=0.65, t(23)=4.01, p<0.01)$ without affecting the private school students $(\beta=0.33, t(23)=1.63$, ns) (Figure 2).

\section{Discussion}

Research highlights the multiplicity of factors influencing the development of social skills. This study investigated the relationships between sociodemographic variables, social skills, and the indication of psychopathology. The results encountered reinforced the idea that there is a relationship between the three dimensions of socially skilled behavior, as previously indicated by Caballo (2003): the behavioral dimension (social skills of adolescents investigated through the IHSA-Del-Prette), the personal dimension (indication of psychopathology, assessed through the SRQ-20, and sociodemographic variables) and situational dimension (type of school attended). variables such as gender and age were investigated. However, unlike previous studies that reported relationships between these variables and social skills in samples of boys and girls from seven to 10 years of age (Bandeira et al., 2006) and of adolescents from 12 to 17 years (Z.A.P. Del Prette \& A. Del Prette, 2009), the sample of this study revealed no differences in the frequency of social skills means according to gender and age. A first 
access to the data indicated that there were differences between gender and age in the difficulty in dealing with social skills, however, these differences disappeared when the indication of psychopathology was controlled. Previous studies (Bakker et al., 2010; Segrin \& Flora, 2000; Wagner \& Oliveira, 2007) have already indicated the relationship between the social skills and psychopathology variables and the present study corroborated this relationship.

The differences between studies on social skills reinforce their contextual character (Caballo, 2003). It is difficult to find consistency among the results, as the context in which the participants are included influences their development. This is due to the fact that different contexts provide varied opportunities for learning social skills and require different social behaviors, which may be useful in one context, but not in others. Other aspects that may interfere with the consistency of the results are sample characteristic: for example, the size and convenience of the sample, and the characterization of the participants (e.g., age, education, and socioeconomic status).

\section{Final Considerations}

The main results of this study indicate that the adolescents with an indication of psychopathology also presented higher rates of difficulties in the Empathy, Civility, Assertiveness and Social resourcefulness subscales of the IHSA-Del-Prette. When seeking possible moderators in the relationship between difficulty in social skills and psychopathology, the only variable identified was the type of school. This variable confirms the importance of the context in the development of social skills. For the adolescents of the public school, the relationship between psychopathology and difficulty in social skills was present. However, this relationship was not significant among the adolescents attending the private school, although some of these also presented an indication of psychopathology. The contexts in which the adolescents of the private school develop can provide them with family and social resources that compensate for the negative effect of the psychopathological symptoms on the development of social skills.

The results found indicate the need for further studies for better comprehension of the relationship between social skills, psychopathology and context. The starting point of this study was the hypothesis that the degree of difficulty in social skills is associated with the presence of an indication of psychopathology, as indicated in the studies by Bakker et al. (2010) and Segrin and Flora (2000). However, this relationship is complex and it is not possible to establish a sense of causality. The results corroborate the information that in the presence of high levels of psychopathology there are deficits in social skills (Landazabal, 2006). Although it was not possible to define the direction of the relationship between social skills and psychopathology, this study allowed the importance of a contextualized approach toward social skills in adolescence to be confirmed. It is essential to know the development of social skills considering the characteristics of the context, of the people and of their attitudes faced with the challenges expected in each step of the life cycle.

\section{References}

Avanci, J. Q., Assis, S. G., Oliveira, R. V., Ferreira, R. M., \& Pesce, R. P. (2007). Fatores associados aos problemas de saúde mental em adolescentes. Psicologia:TeoriaePesquisa,23(3), 287-294.

Bakker, M. P., Ormel, J., Lindenberg, S., Verhulst, F. C., \& Oldehinkel, A. J. (2010). Generation of interpersonal stressful events: The role of poor social skills and early physical maturation in young adolescents - The TRAILS study. Journal of Early Adolescence, 20(10), 1-23.

Bandeira, M., Rocha, S. S., Freitas, L. C., Del Prette, Z. A. P., \& Del Prette, A. (2006). Habilidades sociais e variáveis sociodemográficas em estudantes do ensino fundamental. Psicologia em Estudo, 11(3), 541-549.

Bandeira, M., Rocha, S. S., Pires, L. G., Del Prette, Z. A. P., \& Del Prette, A. (2006). Competência acadêmica de crianças do ensino fundamental: características sociodemográficas e relação com habilidades sociais. Interação, 10(1), 53-62.

Bandeira, M., Rocha, S. S., Souza, T. M. P., Del Prette, Z. A. P., \& Del Prette, A. (2006). Comportamentos problemáticos em estudantes do ensino fundamental: características da ocorrência e relação com habilidades sociais e dificuldades de aprendizagem. Estudos de Psicologia (Natal), 11(2), 199-208.

Bolsoni-Silva, A. T., Marturana, E. D., Pereira, V. A., \& Manfrinato, J. W. S. (2006). Habilidades sociais e problemas de comportamento de pré-escolares: comparando avaliações de mães e professoras. Psicologia: Reflexão e Crítica, 19(3) 460-469.

Branco, C. M., \& Ferreira, E. A. P. (2006). Descrição do atendimento de uma criança com déficit em habilidades sociais. Revista Brasileira de Terapia Comportamental e Cognitiva, 8(1), 25-37. 
Caballo, V. E. (1986). Evaluación de las habilidades sociales. In R. F. Ballesteros \& J. A. Carrobles (Eds.), Evaluación conductual: metodología y aplicaciones (3a ed., pp.553-595). Madrid: Pirâmide.

Caballo, V. E. (2003). Manual de avaliação e treinamento das habilidades sociais. São Paulo: Santos.

Campos, T. N., Del Prette, Z. A. P., \& Del Prette, A. (2000). (Sobre)vivendo nas ruas: habilidades sociais e valores de crianças e adolescentes. Psicologia: Reflexão e Crítica, 13(3), 517-527.

Cecconello, A. M., \& Koller, S. H. (2000). Competência social e empatia: um estudo sobre resiliência com crianças em situação de pobreza. Estudos de Psicologia (Natal), 5(1), 71-93.

Del Prette, Z. A. P., \& Del Prette, A. (1999). Psicologia das habilidades sociais: terapia e educação. Petrópolis: Vozes.

Del Prette, Z. A. P., \& Del Prette, A. (2002). Transtornos psicológicos e habilidades sociais. In H. J. Guillardi (Org.), Sobre comportamento e cognição: contribuições da construção da teoria do comportamento (pp.377-386). Santo André: ESETec.

Del Prette, Z. A. P., \& Del Prette, A. (2009). Inventário de habilidades sociais para adolescentes (IHSA-Del-Prette): manual de aplicação, apuração e interpretação. São Paulo: Casa do Psicólogo.

Erikson, E. H. (1972). Identidade, juventude e crise. Rio de Janeiro: Jorge Zahar.

Falcone, E. M. O. (2000). Habilidades sociais: para além da assertividade. In R. C. Wielenska (Ed.), Sobre comportamento e cognição:questionando e ampliando a teoria e as intervenções clínicas e em outros contextos (Vol. 6). Santo André: ESETec.

Gonçalves, E. S., \& Murta, S. G. (2008). Avaliação dos efeitos de uma modalidade de treinamento de habilidades sociais para crianças. Psicologia: Reflexão e Crítica, 21(3), 430-436.

Harding, T. W., Arango, M. V., Baltazar, J., Climent, C. E., \& Ibrahim, H. H. A. (1980). Mental disorders in primary health care: A study of their frequency and diagnosis in four development countries. Psychological Medicine, 10(2), 231-241.

Knobel, M. (1981). A síndrome da adolescência normal. In A. Aberastury \& M. Knobel. Adolescência normal: um enfoque psicanalítico (pp.24-59). Porto Alegre: Artes Médicas.

Landazabal, M. G. (2006). Psychopathological symptoms, social skills, and personality traits: A study with adolescents. The Spanish Journal of Psychology, 9(2), 182-192.

Mari, J. J., \&Williams, P. (1986). A validity study of a psychiatric screening questionnaire (SRQ-20) in primary care in city of São Paulo. The British Journal of Psychiatry, 148(1), 23-26.

Segrin, C., \& Flora, J. (2000). Poor social skills are a vulnerability factor in the development of psychosocial problems. Human Communication Research, 26(3), 489-514.

Wagner, M. F., \& Oliveira, M. S. (2007). Habilidades sociais e abuso de drogas em adolescentes. Psicologia Clínica, 19(2), 101-116.

Received on: 17/11/2010

Final version on: 10/04/2012

Approved on: 3/5/2012 